\title{
Neurológiai tüneteket okozó double-hit lymphoma
}

\section{Double-hit lymphoma with neurological symptoms}

\author{
Csomor Judit $^{1 @}$, Papp Gergó ${ }^{1}$, Hornyák Csilla ${ }^{2}$, Farkas Péter ${ }^{3}$ \\ ${ }^{1}$ Semmelweis Egyetem, I. sz. Patológiai és Kísérleti Rákkutató Intézet, Budapest \\ ${ }^{2}$ Semmelweis Egyetem, Neurológiai Klinika, Budapest \\ ${ }^{3}$ Semmelweis Egyetem, III. sz. Belgyógyászati Klinika, Budapest \\ (Beérkezett: 2019. május 7.; elfogadva: 2019. június 13.)
}

A 67 éves nőbeteg fél évvel térdprotézismütét után aszimmetrikus, alsó végtagba sugárzó heves fájdalom, végtaggyengeség, érzészavar miatt jelentkezett kezelőorvosánál. A rapidan progrediáló neurológiai tünetek kivizsgálása során (SE Neurológiai Klinika) panaszait okozó mütéti szövődményt, spondylitist, meningeális/központi idegrendszeri térfoglaló daganatot, autoimmun betegséget kizártak. Nagy dózisú szteroid, plazmaferezis állapotán nem javított. Mivel a lázzal nem járó magas liquor protein, LDH, CRP és süllyedés hátterében infekciót nem találtak, az EMG lelet alapján demyelinizációval nem kí- sért neurális léziónak, lumbosacralis polyradiculitisnek tartott betegség paraneoplasztikus eredete merült fel. Teljestest-CT kiterjedt testüregi nyirokcsomó-megnagyobbodást talált.

A diagnosztikus csontvelő-biopszia idejében, másfél hónappal a tünetek kezdete után, a beteg paraparetikus, vegetatív idegrendszeri tünet nélkül. Állapotát uroszepszis rontja, intenzív osztályos kezelésre szorul. Fehérvérsejtszáma 10 ezer feletti, atípusos sejtekkel. Csontvelőelégtelensége gyorsan romlik, LDH-ja extrém magas értékre emelkedik.

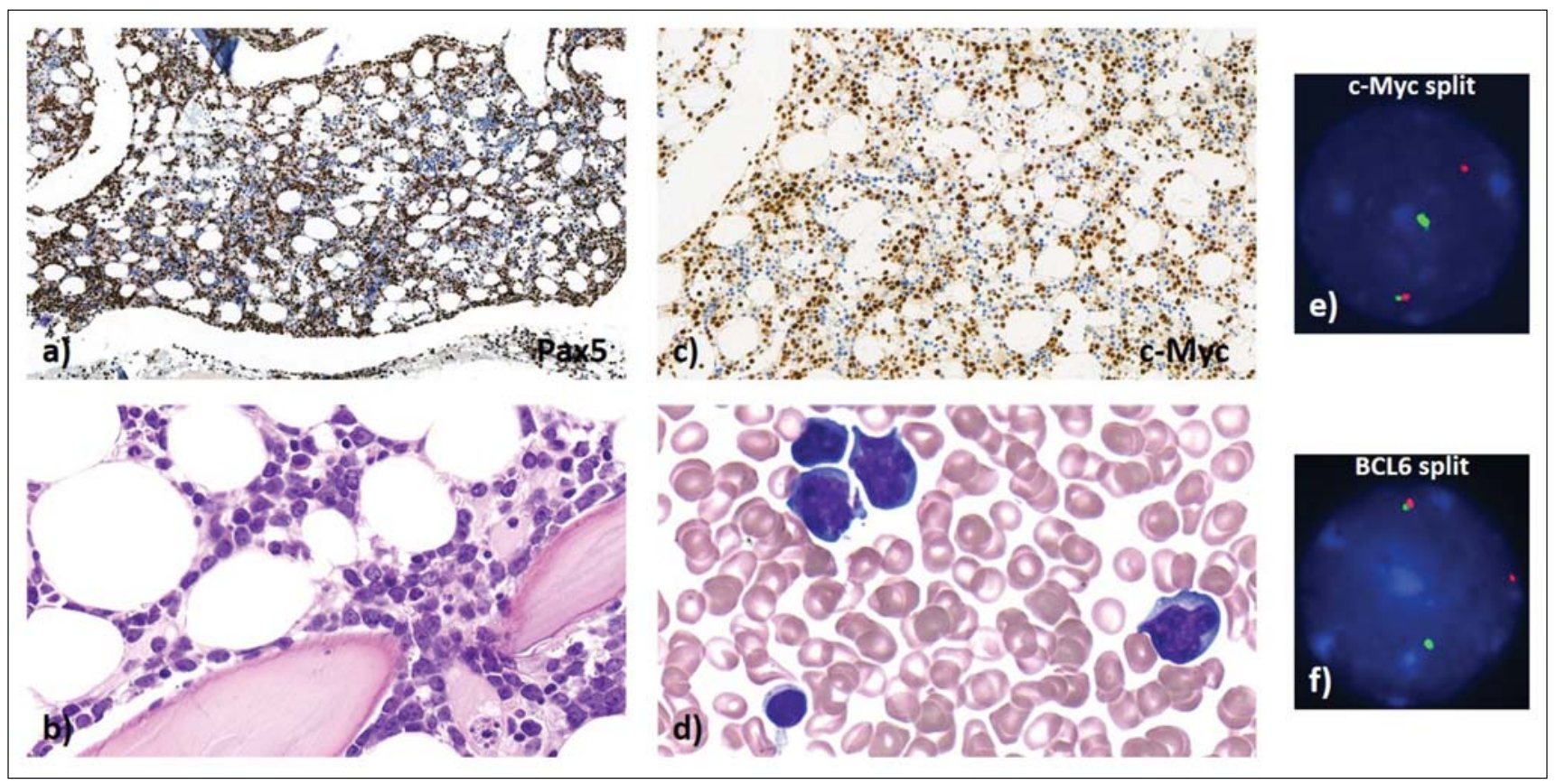

1. ábra. A csontvelőt interstitialisan, leukémiaszerűen $\mathrm{CD} 20+, \mathrm{CD} 10+, \mathrm{bcl} 6+$, bcl2+, MUM1+ centroblastok infiltrálják. A proliferációs ráta $70 \%$, a c-Myc expresszió 100\%-os (a)-c)). FISH-vizsgálat során c-Myc és BCL6 géntörés (e)-f)) igazolódott. Vérben 30\% lambda monoklonális CD10dim/neg, CD38-pozitív B-sejt (d))

@ Levelezési cím: Csomor Judit, Semmelweis Egyetem, I. sz. Patológiai és Kísérleti Rákkutató Intézet, 1085 Budapest, Üllői út $26 . ;$ Tel.: +3620825 0265; E-mail: jmj.csomor@gmail.com 
A hematológiai kivizsgálás (CT, csípőlapát-biopszia, perifériás vér áramlási cytometria) eredménye (SE III. sz. Belgyógyászati Klinika, I. sz. Patológia):

Diagnózis - High grade B-sejtes lymphoma double-hit, leukémiás vérképpel (1.ábra).

Uroszepszisét szanálták, de az R-CHOP-kezelés (a korábban két ízben negatív liquor cytológia és a súlyos thrombocytopenia miatt intrathecalis kemoterápiát nem kapott) okozta apláziás szakaszban szeptikus sokk tünetei között exitált. Boncoláskor (I. sz. Patológia) nyirokcsomók már nem voltak. A gerincvelő és gyökök szövettani feldolgozására nem került sor, ezért neurolymphomatosis lehetősége - mint a legfontosabb differenciáldiagnosztikus kórkép - teljes biztonsággal nem zárható ki.

A high grade double-hit lymphoma a 2016-os WHO klasszifikációban új entitás, az összes DLBCL kevesebb mint 10\%-a. Agresszív lymphomatípus, prognózisa standard kezelés mellett is rossz [1]. Lymphomához társuló paraneoplasztikus neurológiai szindrómák rendkívül ritkák [2]. Hodgkin-lymphomában leginkább limbikus encephalitis, NHL-ben sensomotoros neuropathia és dermatomyositis fordul elő. Szolid tumorokkal ellentétben a paraneoplasztikus szindróma elörehaladott lymphoma mellett alakul ki, és benne neuronellenes antitestek nem detektálhatóak.

Nyilatkozat: A kézirat korábban más folyóiratban nem jelent meg, és máshova beküldésre nem került. A szerzők anyagi támogatásban nem részesültek.

Érdekeltségek: A szerzőknek nincsenek a közleményhez kapcsolódó közvetlen érdekeltségeik.

Szerzői munkamegosztás: Cs. J., F. P., H. CS.: a kézirat el= készítése; Cs. J., P. G.: az ábraanyag képeinek összeállítása. A kézirat végleges változatát minden szerző elolvasta és jóváhagyta.

\section{Irodalom}

[1] Friedberg JW. How I treat double-hit lymphoma. Blood, 2017; 130: 590-596.

[2] Graus F, Arino H, Dalmau J. Paraneoplastic neurological syndromes in Hodgkin and non-Hodgkin lymphomas. Blood, 2014; 123: $3230-3238$.

A cikk a Creative Commons Attribution 4.0 International License (https://creativecommons.org/licenses/by/4.0/) feltételei szerint publikált Open Access közlemény, melynek szellemében a cikk bármilyen médiumban szabadon felhasználható, megosztható és újraközölhető, feltéve, hogy az eredeti szerző és a közlés helye, illetve a CC License linkje és az esetlegesen végrehajtott módosítások feltüntetésre kerülnek. (SID_1) 